\title{
GLOSSARY
}

\section{DEFENSE ACQUISITION ACRONYMS AND TERMS}

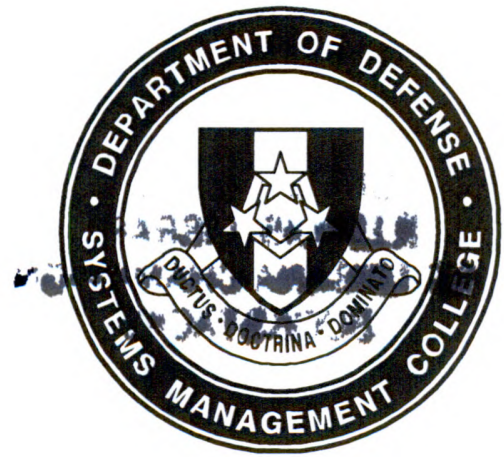

\section{Department of Defense \\ Defense Systems Management College \\ Acquisition Policy Department \\ Fort Belvoir, Virginia}

Ninth Edition

November 1998 